Purdue University Purdue e-Pubs

$11-14-2018$

\title{
Fake News, Special Libraries and What It Means to Be American
}

Ilana Stonebraker

Purdue University, stonebraker@purdue.edu

Emily Johnson

emilyjohnson314@gmail.com

Follow this and additional works at: https://docs.lib.purdue.edu/lib_fsdocs

\section{Recommended Citation}

Stonebraker, I., \& Johnson, E. (2018). Fake News, Special Libraries and What It Means to Be American. Public Services Quarterly, 14(2), 193-195.

This document has been made available through Purdue e-Pubs, a service of the Purdue University Libraries. Please contact epubs@purdue.edu for additional information. 
Fake News, Special Libraries and What It Means to Be American

Librarians have been banging the "fake news" gong for much longer than most fake news writers have been alive (Sydell, 2016). We offer here our perspective on "fake news", as librarians at an international school and a business library. This column will focus less on where "fake news" came from or why it seems to spread, but why does "fake news" matter to us at all? Why can't we just ignore it, or walk away? Why is "fake news" so detestable to us?

As Finn Brunton argues in his book, what is not information tells a lot about we view information, like how a shadow can inform a shape. We librarians compare our experiences with Chinese students because it allows us see exactly how much the "fake news" phenomenon tells us about it means to be an American. Acknowledging the specific cultural misunderstandings or assumptions that we have about our students allows us to see the "shape" of the shadow our information understanding casts. The more you work with students from China in an American university, the more aware you are of how different an information experience can be. For many Americans, being a citizen is contingent upon our understanding of news and the issues which present themselves daily in our civic lives (Brunton, 2013).

From a very early age Americans are taught to be wary of the motives of others. We are taught to challenge authority, to question those in leadership and to demand answers. It is even enshrined in our foundational documents. For many of us the American experience means questioning information and the power that creates it. Chinese students are taught that knowledge, and anyone who possesses it, is very 
powerful, and thus should be shown great respect. ${ }^{1}$ This doesn't necessarily preclude Chinese students from being taken in by sensational news stories, but it does make them warier of all news, not just those whose motivations are dubious.

The idea of some information being fake versus some being real assumes a hierarchy of ownership. Students in the United States are given the tools and understanding that the information they use needs to be cited to the original source even if it isn't always done correctly. In fact, there are multiple style guides and formats for these citations. However, there are no such standardized citation styles in China. It is not uncommon for Chinese students to copy and paste entire sections of online resources, with no citations or references. They've never been taught that is inappropriate and there are no tools available to them to help with creating citations. This is unthinkable to an American student.

In the American folkways of information, we pride ourselves on "pulling ourselves up by our bootstraps," ${ }^{2}$ But these cultural differences bleed into how we view information: This lack of understanding comes from the very different cultural norms between Chinese and American students. Chinese culture is very communal and social in nature. Great value is placed on Chinese students working towards the common good of society, ignoring their own personal desires. American culture, on the other hand, is very individualistic in China, information is communal and free to all, while in

\footnotetext{
${ }^{1}$ Before we go any further, let us say that we do not believe that either American or Chinese culture is monolithic. There are vast differences between Chinese students educated at international versus bilingual versus public versus rural schools. Additionally there are differences between younger students (such as 18 year-olds) and older students. On the American side, there is differences between how students see information in an undergraduate journalism class versus a graduate seminar.

${ }^{2}$ Even though this is actually a logical fallacy https://abetterworldisprobable.wordpress.com/2011/05/17/pulling-yourself-up-by-your-bootstraps-anetymology-of-an-american-dream/
}

Stonebraker and Johnson 2 
America, it has to be bought and paid for. "Fake news" is just another element of our cultural knowledge.

So what does "fake news" tell us about being American? Quite a lot. More than just an unfortunate, nefarious output of the internet, "fake news" actually serves an important purpose in our information ecosystem. We turn the question back to you, humble reader: what makes news "fake" and why does that matter? The next time you find yourself looking up the latest hoax on Snopes, think about how this misinformation makes you all the more aware of how important information is to our daily lives, as Americans, as students, teachers, and yes, even as librarians.

\section{Works Cited}

Brunton, F. (2013). Spam: A shadow history of the Internet. MIT Press.

Sydell, L. (2016, November 23). We Tracked Down A Fake-News Creator In The Suburbs. Here's What We Learned. National Public Radio. Retrieved from https://www.npr.org/sections/alltechconsidered/2016/11/23/503146770/npr-findsthe-head-of-a-covert-fake-news-operation-in-the-suburbs 